\title{
Dietary Utilisation of Protein and Energy from Fresh and Ensiled Coffee Pulp by the Nile tilapia, Oreochromis niloticus
}

\author{
Yann Moreau $^{1 *}$, Jose-Luis Arredondo ${ }^{2}$, Isabelle Perraud-Gaime ${ }^{3}$ and Sevastianos Roussos ${ }^{3}$ \\ ${ }^{1}$ GAMET; Institut de Recherche pour le Développement; IRD; B. P. 5095; Yann.Moreau@mpl.ird.fr; 34033 \\ Montpellier - France. ${ }^{2}$ Planta Experimental de Produccíon Acuicola; Universitad Autónoma Metropolitana; \\ Unidad de Iztapalapa - UAM-I; Av Michoacan y la Purisima s/n; D. F. 09340; Col. Vicentina Iztapalapa - Mexico. \\ ${ }^{3}$ Laboratoire de Microbiologie; IRD; IFR-BAIM; Université de Provence; Case 925; ESIL; 163 Av. de Luminy; \\ 13288 Marseille Cedex 9; France
}

\begin{abstract}
Dietary protein and energy utilisation of diets containing fresh and ensiled coffee pulp were studied on $3.2 \pm 0.2 \mathrm{~g}$ Nile tilapia for 28 days. Diets formulation and feeding were designed on the basis of daily dietary protein and energy allowance. A control diet A (100\% protein and $100 \%$ energy allowance) corresponding to $15 \mathrm{~g} \mathrm{CP} \mathrm{kg}^{-1}$ day ${ }^{-1}$ and $750 \mathrm{~kJ} \mathrm{~kg}^{-1}$ day $^{-1}$, a low protein control diet B (80\% protein and $100 \%$ energy allowance), two diets $C$ and $E$ (100\% protein and $100 \%$ energy allowance) where $20 \%$ of protein were supplied by coffee pulp, and two diets $D$ and $F$ with the same amount of coffee pulp than in $C$ and $E$ and supplementation in non-protein energy. Inclusion of coffee pulp in the diet strongly impaired growth and feed utilisation. Silage process improved overall feed utilisation comparing to fresh coffee pulp. Results showed that fresh or ensiled coffee pulp was not a suitable feedstuff for Nile tilapia. However, better knowledge on modification occurring during silage process could allow finding the way to significantly improve nutritive value of coffee pulp by-products.
\end{abstract}

\begin{abstract}
Abbreviations: CP, crude protein; DE, digestible energy ; GE, gross energy ; NFE, nitrogen free extract ; FCR, food conversion ration, SGR, specific growth rate ; NPU, apparent net protein utilization; ADC, apparent digestibility coefficient; FCP, fresh coffee pulp; ECP, ensiled coffee pulp
\end{abstract}

Keywords: Coffee pulp, silage, aquaculture, cichlids, feedstuff, fish

\section{INTRODUCTION}

As nearly $45 \%$ of the cherry, coffee pulp is one of the main by-product of coffee agro-industry and represents a valuable potential for several purposes including feedstuff for animal in coffee producing countries (Pandey et al., 2000). Several trials have been done on cattle and poultry (Abate and Pfeffer, 1986; Cabezas et al., 1974; Donkoh et al., 1988; Gomez-Brenes et al., 1985; Okai and Dabo, 1991). Utilisation of coffee pulp is reported to reduce growth rate and feed intake, or to induce mortality. These adverse effects were associated to high lignocellulosic fraction and to toxic and/or anti-nutrient content as alkaloid (caffeine and theobromine) and tannin (Aregheore, 1998).

\footnotetext{
* Author for correspondence
} 
Incorporation of coffee pulp to diets were also tested on several fish species (Bautista et al., 1999; Bayne et al., 1976; Christensen, 1981; Fagbenro and Arowosoge, 1991; Ulloa Rojas and van Weerd, 1997). Adverse effect on growth depletion was reported for fish but not strong mortality. Negative impact on growth remained limited under low incorporation and coffee pulp was considered as a potentially useful feedstuff for some species, Clarias isheriensis (Fagbenro and Arowosoge, 1991) or hybrids between species from Colossoma and Piaractus genera (Bautista et al., 1999). Coffee pulp is a by-product of wet coffee processing and may not be conserved without treatment. Silage is reported to be a valuable technique for either conservation and improvement of its nutritive value (Gomez-Brenes et al., 1988). Silage process was recently improved in Mexico where wet processing is the main way coffee bean preparation (Roussos et al., 2000). The objective of this work was to compare fresh and ensiled coffee pulp as a potential feedstuff for the Nile tilapia, Oreochromis niloticus. Special attention was paid to protein and energy utilization.

\section{MATERIAL AND METHODS}

Coffee pulp and feedstuff: Coffee pulp was obtained from a processing plant in Jalapa (Vera Cruz, Mexico). Fresh processed coffee pulp was frozen and conserved at $-20^{\circ} \mathrm{C}$. Ensiled coffee pulp was prepared and conserved for ten months as previously described (Perraud-Gaime et al., 2000). Both fresh and ensiled coffee pulp were dried $\left(24 \mathrm{~h}, 70{ }^{\circ} \mathrm{C}\right)$ and finely ground before feed preparation. High quality fishmeal (Islande $70^{\mathrm{TM}}$, SANOFI) and pre-gelatinised corn starch were used as protein and energy supply in control diet. Corn oil and premix were added to supply suitable quantity of essential fatty acid, vitamins and minerals. Sodium alginate was used as binder and chromic oxide as digestibility marker. Proximate analysis of fresh coffee pulp (FCP), ensiled coffee pulp (ECP), fishmeal and cornstarch is given in table 1.

Table 1 - Proximate analysis of main feedstuffs used for the preparation of experimental diets.

\begin{tabular}{lccccccc}
\hline \multirow{2}{*}{ Feedstuffs } & \multicolumn{7}{c}{ Components (for 100 g dry matter) } \\
\cline { 2 - 8 } & $\begin{array}{c}\text { Crude } \\
\text { protein } \\
(\mathbf{g})\end{array}$ & $\begin{array}{c}\text { Ether } \\
\text { extract } \\
(\mathbf{g})\end{array}$ & $\begin{array}{c}\text { NFE } \\
(\mathbf{g})\end{array}$ & $\begin{array}{c}\text { Crude fibre } \\
(\mathbf{g})\end{array}$ & $\begin{array}{c}\text { Crude ash } \\
(\mathbf{g})\end{array}$ & $\begin{array}{c}\text { Gross } \\
\text { energy* } \\
(\mathbf{k J})\end{array}$ & $\begin{array}{c}\text { Digestible } \\
\text { energy* } \\
(\mathbf{k J})\end{array}$ \\
\hline Fresh coffee pulp & 13.14 & 2.85 & 53.55 & 14.31 & 7.73 & 1344 & 1112 \\
Ensiled coffee pulp & 9.12 & 1.54 & 63.50 & 20.91 & 9.55 & 1368 & 1119 \\
Fishmeal & 80.23 & 8.55 & 0.00 & 0.00 & 14.72 & 2231 & 1976 \\
Cornstarch & 0.00 & 0.04 & 99.26 & 0.00 & 0.70 & 1709 & 1589 \\
\hline
\end{tabular}

* Calculated

Fish and experimental facilities: Experiment was performed at the GAMET (Montpellier, France) in a closed water system including 18 fibreglass tanks of 70 litres. Water temperature was regulated at $28 \pm 1{ }^{\circ} \mathrm{C}$. No adverse condition in water quality (dissolved oxygen or ammonia content) was observed during the experiment. The daily photoperiod was maintained to $12 \mathrm{~L}: 12 \mathrm{D}$ with fluorescent tubes. Nile tilapia, Côte d'Ivoire strain, were locally produced and grew in aquarium using commercial feed (Ecolife $^{\mathrm{TM}}$, Aqualim) until suitable size $(3.2 \pm 0.2 \mathrm{~g}$ mean body weight). Before the experiment, fishes were individually weighted and randomly spread in 18 groups of 10. Another group of 10 was killed and kept frozen for analysis of initial condition. Total fish body mass in each tank was checked every week to adjust feeding rate. At the end of experiment, 28 days after, fishes were weighted individually, slaughtered and frozen before analysis. In all cases, fishes were anaesthetised before handling (2-phenoxyethanol $0.1 \mathrm{ml} \mathrm{l}^{-1}$ ). Upon analysis, frozen fishes were chopped, lyophilised and ground to obtain a homogenous dry fine powder. 
Table 2 - Pattern of protein and energy dietary daily allowance for each experimental diet as percent of control.

\begin{tabular}{lcccccc}
\hline Diet & A & B & C & D & E & F \\
Crude protein (\%) & & & & & & \\
fishmeal & 100 & 80 & 80 & 80 & 80 & 80 \\
fresh coffee pulp & 0 & 0 & 20 & 20 & 0 & 0 \\
ensiled coffee pulp & 0 & 0 & 0 & 0 & 20 & 20 \\
Digestible energy (\%) & & & & & & \\
fishmeal & 49 & 39 & 39 & 39 & 39 & 39 \\
fresh coffee pulp & 0 & 0 & 49 & 49 & 0 & 0 \\
ensiled coffee pulp & 0 & 0 & 0 & 0 & 34 & 34 \\
others & 51 & 61 & 12 & 51 & 27 & 51 \\
\hline
\end{tabular}

Table 3 - Composition (\% dry matter) and practical feeding rate $\left(\mathrm{g} \mathrm{kg}^{-1} \mathrm{day}^{-1}\right)$ for each experimental diet fed to Nile tilapia.

\begin{tabular}{|c|c|c|c|c|c|c|}
\hline \multirow[t]{2}{*}{ Ingredients } & \multicolumn{6}{|c|}{ Diet } \\
\hline & $\mathbf{A}$ & B & $\mathbf{C}$ & D & $\mathbf{E}$ & $\mathbf{F}$ \\
\hline Cornstarch & 50.0 & 59.5 & 6.0 & 29.8 & 20.3 & 34.6 \\
\hline Fishmeal & 43.0 & 33.6 & 27.5 & 20.5 & 29.1 & 23.8 \\
\hline Ensiled coffee pulp & 0.0 & 0.0 & 0.0 & 0.0 & 44.4 & 36.3 \\
\hline Fresh coffee pulp & 0.0 & 0.0 & 60.5 & 45.0 & 0.0 & 0.0 \\
\hline Corn oil & 2.1 & 2.0 & 1.7 & 1.2 & 1.8 & 1.4 \\
\hline Vitamin premix ${ }^{1}$ & 0.7 & 0.7 & 0.6 & 0.4 & 0.6 & 0.5 \\
\hline Mineral premix ${ }^{2}$ & 2.8 & 2.7 & 2.2 & 1.6 & 2.3 & 1.9 \\
\hline Binder ( $\mathrm{Na}$ alginate) & 1.0 & 1.0 & 1.0 & 1.0 & 1.0 & 1.0 \\
\hline $\operatorname{Marker}\left(\mathrm{Cr}_{2} \mathrm{O}_{3}\right)$ & 0.5 & 0.5 & 0.5 & 0.5 & 0.5 & 0.5 \\
\hline Feeding rate & 43.5 & 44.5 & 54.3 & 73.1 & 51.4 & 62.9 \\
\hline
\end{tabular}

Table 4 - Proximate analysis (for $100 \mathrm{~g}$ dry matter) and daily dietary allowance $\left(\mathrm{kg}^{-1} \mathrm{day}^{-1}\right)$ for each the experimental diets.

\begin{tabular}{|c|c|c|c|c|c|c|}
\hline & \multicolumn{6}{|c|}{ Diet } \\
\hline & A & $\mathrm{B}$ & $\mathrm{C}$ & $\mathrm{D}$ & $\mathrm{E}$ & $\mathrm{F}$ \\
\hline \multicolumn{7}{|l|}{ Components } \\
\hline Crude protein $(\mathrm{g})$ & 32.6 & 25.3 & 25.6 & 19.3 & 26.9 & 21.3 \\
\hline Ether extract (g) & 6.1 & 4.8 & 5.1 & 3.8 & 4.7 & 3.2 \\
\hline Crude fibre (g) & 0.0 & 0.0 & 12.7 & 9.4 & 6.4 & 5.2 \\
\hline Crude ash (g) & 9.9 & 8.0 & 11.2 & 8.5 & 10.7 & 9.0 \\
\hline $\operatorname{NFE}(g)^{1}$ & 51.4 & 61.9 & 45.5 & 59.0 & 51.3 & 61.2 \\
\hline Gross energy $(\mathrm{kJ})^{2}$ & 1894 & 1851 & 1588 & 1619 & 1704 & 1684 \\
\hline Digest. energy $(\mathrm{kJ})^{2}$ & 1604 & 1550 & 1341 & 1348 & 1436 & 1404 \\
\hline \multicolumn{7}{|c|}{ Daily dietary allowance } \\
\hline Crude protein $(\mathrm{g})$ & 14.2 & 11.2 & 13.9 & 14.1 & 13.8 & 13.4 \\
\hline Digest. energy $(\mathrm{kJ})^{2}$ & 698 & 689 & 728 & 985 & 738 & 883 \\
\hline
\end{tabular}

${ }^{1}$ Nitrogen free extract

${ }^{2}$ Calculated. 
Diets: Practical diets were formulated in order to adjust specific daily dietary protein and energy allowance (Table 2). A control diet A was designed to provide a daily protein and energy allowance of $15 \mathrm{~g} \mathrm{CP} \mathrm{kg}^{-1} \mathrm{day}^{-1}$ and $750 \mathrm{~kJ} \mathrm{DE}$ $\mathrm{kg}^{-1}$ day $^{-1}$, respectively, according to Nile tilapia requirements (Kaushik et al., 1995). This was referred as $100 \%$ protein and $100 \%$ energy supply. To compare results obtain with and without coffee pulp, a low protein control diet B corresponding to $80 \%$ protein allowance and $100 \%$ energy allowance was also designed. In diets $\mathrm{C}$ and $\mathrm{E}$, incorporation level of fresh or ensiled coffee pulp was arbitrary chosen to cover $20 \%$ of daily dietary protein allowance. To check true utilisation of non-protein energy content in coffee pulp, two other diets, D and F, were also planned to provide an amount of non-protein energy equal to those in the control $\operatorname{diet} \mathrm{A}$ as corn starch. Formulation and feeding rate were adjusted for each diet according to these objectives for daily protein and energy allowance (Table 3). Results of proximate analysis of experimental diet are given in Table 4. All treatments except B were isoproteic with respect to both diet crude protein content and applied feeding rate, whereas treatments were isocaloric except D and F. For these last two diets, non-protein digestible energy coming from fresh or ensiled coffee pulp represented 41 and $21 \%$ percent of total digestible energy allowed in control diet, respectively. All diets were prepared wet, using an electric mincer equipped with a $1.5 \mathrm{~mm}$ sieve. Pelleted feed were manually crushed to appropriate size, aliquoted in hermetic plastic bag and kept at $-20^{\circ} \mathrm{C}$ until utilisation. Each week, bags were allowed to defrost at $4{ }^{\circ} \mathrm{C}$ and dry matter was determined to calculate rations. Daily rations were given in two equal meals at 9:00 and 17:00h.

Analysis: Proximate composition analysis were performed for carcass, feed and faecal sample. Dry matter was determined after drying at $105^{\circ} \mathrm{C}$, and ash content after heating at $500^{\circ} \mathrm{C}$. Crude protein content was estimated as 6.25 -fold nitrogen content as given by the Kjeldahl method. Crude fat content was measured by gravimetry after extraction with petroleum ether using a Soxhlet device. Crude fibre content was measured in fresh and ensiled coffee pulp using Weende method (Hart and Fisher, 1971). Nitrogen free extract was used to estimate carbohydrate content. Gross energy was estimated using the following coefficients: $23.6 \mathrm{~kJ} \mathrm{~g}^{-1}$ for crude protein; $39.5 \mathrm{~kJ}$ $\mathrm{g}^{-1}$ for crude fat and $17.2 \mathrm{~kJ} \mathrm{~g}^{-1}$ for carbohydrates (N.R.C., 1993). Before experiment, estimates of digestible energy content in feed were calculated using default apparent coefficients of digestibility of $0.9,0.85$ and 0.8 for crude protein, crude fat and carbohydrates, respectively. At the end of the experiment, apparent digestibility of dry matter, protein and lipids, were measured using chromic oxide $\left(\mathrm{Cr}_{2} \mathrm{O}_{3}\right)$ as marker. Chromic oxide were analysed according to (Suzuki and Early, 1991).

Calculation: Apparent digestibility coefficients ADC were calculated for each nutrient using the usual formulae (Cho et al., 1985):

$$
\mathrm{ADC}=1-\left(\frac{\% \mathrm{Cr} \text { in feed } \times \% \text { nutrient in faeces }}{\% \mathrm{Cr} \text { in faeces } \times \% \text { nutrient in feed }}\right)
$$

Others feed utilisation and growth performance indices were calculated as follow:

- Food conversion ratio:

$$
\mathrm{FCR}=\frac{\text { Ingested feed (dry) }}{\text { Mass increase (wet) }}
$$

- Specific growth rate:

$$
\mathrm{SGR}=\frac{\log _{\mathrm{e}}\left(\mathrm{M}_{\mathrm{f}}\right)-\log _{\mathrm{e}}\left(\mathrm{M}_{\mathrm{i}}\right)}{\text { Time interval (days) }}
$$

with $\mathrm{M}_{\mathrm{f}}$ and $\mathrm{M}_{\mathrm{i}}$, final and initial mean body mass, respectively;

- Apparent net protein utilization :

$$
\mathrm{NPU}=\frac{\text { Crude protein increase }}{\text { Ingested crude protein }}
$$

Specific growth rates were also computed for crude protein, crude fat and gross energy and apparent nutrient utilisation for crude fat and gross energy.

Statistical analysis: Analysis of variance methods were used to examine the results. These were computed using the GLM or MIXED procedure of 
SAS software (SAS Institute Inc., 1989). A significant level of 0.05 was retained for each test.

\section{RESULTS}

Survival, gain and growth: No mortality was observed during the 28 days duration of the experiment. All diets were readily accepted by fishes, which remained healthy. Final body masses were higher with the control diets (A and B) than with all coffee pulp containing diets (Table 5).

Significantly higher final body masses were obtained with ensiled coffee pulp supplemented with corn starch compared to all other coffee pulp containing diets. Decrease in average body mass was only observed with diet $\mathrm{C}$ containing fresh coffee pulp. Incorporation of coffee pulp induced strong reduction in crude protein gain and losses in body fat. Same pattern was obtained for growth performance (Table 6).

Incorporation of either fresh or ensiled coffee pulp in the diet induced a strong depletion of growth. However, adding a supplement of corn starch to these diet allowed a slight improve of body growth. Better performances were obtained with ensiled coffee pulp than with fresh one. With inclusion of coffee pulp, overall variations in body fat and protein content indicated a loss in gross energy content associated primarily to fat depletion, except with diet F. Among control diets, higher growth rate and protein deposition were observed with diet A.

Nutrient utilisation: Incorporation of coffee pulp in diets strongly impaired FCR, ADC and apparent nutrient utilisation value (Table 7). FCR values obtained with ensiled coffee pulp were significantly better than those with fresh coffee pulp. ADC for organic matter was high for the two control diets even with the diet B containing nearly $60 \%$ of starch. For the four coffee pulpcontaining diets, ADC's were strongly reduced being close to $50 \%$. Higher organic matter ADC was noted for diet $\mathrm{F}$ compares to $\operatorname{diet} \mathrm{C}, \mathrm{D}$ and $\mathrm{E}$. No specific trends could be observed between crude proteins ADC with fresh or ensiled coffee pulp. With fresh pulp without supplementation of cornstarch (diet C), fish appeared unable to use crude protein and crude fat supply from feed. For both kind of coffee pulp, addition of cornstarch improved apparent protein and fat utilisation. Whatever the diet containing coffee pulp, apparent utilisation of crude fat remained negative indicating that fat supply was unable to cover fish needs. Except for diet F, gross energy provided by coffee pulp containing diet was helpless to satisfy fish needs.

Table 5 - Average initial and final body mass $(\mathrm{g})$ and average gain $(\mathrm{g})$ in fresh and dry matter, crude protein and crude fat of Nile tilapia fed with the six experimental diets for 28 days. Values in rows with different superscripts are significantly different (Tukey test, $\mathrm{P}>0.05$ ).

\begin{tabular}{lcccccc} 
& \multicolumn{7}{c}{ Diet } \\
\cline { 2 - 8 } & \multicolumn{7}{c}{$\mathbf{A}$} & $\mathbf{B}$ & $\mathbf{C}$ & $\mathbf{D}$ & $\mathbf{E}$ & $\mathbf{F}$ \\
\hline Average mass (g) & & & & & & \\
Initial & $3.13^{\mathrm{a}}$ & $3.18^{\mathrm{a}}$ & $3.18^{\mathrm{a}}$ & $3.08^{\mathrm{a}}$ & $3.27^{\mathrm{a}}$ & $3.31^{\mathrm{a}}$ \\
Final & $8.23^{\mathrm{a}}$ & $7.22^{\mathrm{b}}$ & $3.02^{\mathrm{c}}$ & $3.36^{\mathrm{cd}}$ & $3.92^{\mathrm{cd}}$ & $4.37^{\mathrm{d}}$ \\
Average gain (g) & & & & & & \\
Fresh matter & $5.09^{\mathrm{a}}$ & $4.04^{\mathrm{b}}$ & $-0.16^{\mathrm{e}}$ & $0.28^{\mathrm{d}}$ & $0.65^{\mathrm{dc}}$ & $1.06^{\mathrm{c}}$ \\
Dry matter & $1.25^{\mathrm{a}}$ & $1.02^{\mathrm{b}}$ & $-0.16^{\mathrm{e}}$ & $0.02^{\mathrm{d}}$ & $0.05^{\mathrm{d}}$ & $0.22^{\mathrm{c}}$ \\
Crude protein & $0.75^{\mathrm{a}}$ & $0.56^{\mathrm{b}}$ & $-0.05^{\mathrm{e}}$ & $0.05^{\mathrm{d}}$ & $0.09^{\mathrm{d}}$ & $0.18^{\mathrm{c}}$ \\
Crude fat & $0.23^{\mathrm{a}}$ & $0.24^{\mathrm{a}}$ & $-0.15^{\mathrm{d}}$ & $-0.09^{\mathrm{c}}$ & $-0.12^{\mathrm{dc}}$ & $-0.02^{\mathrm{b}}$ \\
\hline
\end{tabular}


Table 6 - Specific growth rate $\left(\%\right.$ day $\left.^{-1}\right)$ in body mass, crude protein, crude fat and gross energy of Nile tilapia receiving the six diets during 28 days. Values in rows with different superscripts are significantly different (Tukey test, $\mathrm{P}>0.05)$.

\begin{tabular}{|c|c|c|c|c|c|c|}
\hline \multirow{2}{*}{ SGR } & \multicolumn{6}{|c|}{ Diet } \\
\hline & $\mathbf{A}$ & B & $\mathbf{C}$ & D & $\mathbf{E}$ & $\mathbf{F}$ \\
\hline Body mass & $3.45^{\mathrm{a}}$ & $2.93^{\mathrm{b}}$ & $-0.18^{\mathrm{f}}$ & $0.31^{\mathrm{e}}$ & $0.64^{\mathrm{d}}$ & $0.99^{\mathrm{c}}$ \\
\hline Crude protein & $3.46^{\mathrm{a}}$ & $2.80^{\mathrm{b}}$ & $-0.41^{\mathrm{e}}$ & $0.36^{\mathrm{d}}$ & $0.63^{\mathrm{d}}$ & $1.12^{\mathrm{c}}$ \\
\hline Crude fat & $2.68^{\mathrm{a}}$ & $2.73^{\mathrm{a}}$ & $-4.39^{\mathrm{d}}$ & $-2.07^{\mathrm{c}}$ & $-2.75^{\mathrm{c}}$ & $-0.41^{\mathrm{b}}$ \\
\hline Gross energy & $3.14^{\mathrm{a}}$ & $2.77^{\mathrm{a}}$ & $-1.61^{\mathrm{d}}$ & $-0.49^{c}$ & $-0.45^{\mathrm{c}}$ & $0.55^{\mathrm{b}}$ \\
\hline
\end{tabular}

Table 7 - Food conversion ration (FCR), apparent digestibility coefficient (ADC) and apparent nutrient utilisation of Nile tilapia receiving the six diets during 28 days. Values in rows with different superscripts are significantly different (Tukey test, $P>0.05$ )

\begin{tabular}{|c|c|c|c|c|c|c|}
\hline \multirow[t]{2}{*}{ Indices } & \multicolumn{6}{|c|}{ Diet } \\
\hline & $\mathbf{A}$ & B & $\mathbf{C}$ & D & $\mathbf{E}$ & $\mathbf{F}$ \\
\hline FCR & $0.98^{\mathrm{c}}$ & $1.20^{\mathrm{c}}$ & $-27.09^{d}$ & $20.80^{\mathrm{a}}$ & $7.45^{\mathrm{b}}$ & $5.65^{\mathrm{cb}}$ \\
\hline \multicolumn{7}{|l|}{$A D C(\%)$} \\
\hline Dry matter & 88,2 & 84,3 & 57,3 & 51,4 & 47,1 & 60,9 \\
\hline Organic matter & 89,5 & 91,2 & 56,2 & 52,8 & 56,2 & 89,5 \\
\hline Crude protein & 91,6 & 85,6 & 45,7 & 59,6 & 51,6 & 54,9 \\
\hline \multicolumn{7}{|c|}{ Apparent net utilisation } \\
\hline Crude protein & $0.46^{\mathrm{a}}$ & $0.46^{\mathrm{a}}$ & $-0.05^{\mathrm{d}}$ & $0.04^{\mathrm{c}}$ & $0.07^{\mathrm{c}}$ & $0.14^{\mathrm{b}}$ \\
\hline Crude fat & $0.77^{\mathrm{b}}$ & $1.03^{\mathrm{a}}$ & $-0.68^{\mathrm{e}}$ & $-0.40^{\mathrm{d}}$ & $-0.53^{\text {ed }}$ & $-0.12^{\mathrm{c}}$ \\
\hline Gross energy & $0.29^{\mathrm{a}}$ & $0.25^{\mathrm{b}}$ & $-0.10^{\mathrm{e}}$ & $-0.03^{\mathrm{d}}$ & $-0.03^{\mathrm{d}}$ & $0.03^{\mathrm{c}}$ \\
\hline
\end{tabular}

\section{DISCUSSION}

As no mortality or apparent diseases were observed all over the 28-day experiment, fresh and ensiled coffee pulp should not be considered poisonous for Nile tilapia. Difference in growth performance and protein deposition between the two control diets $\mathrm{A}$ and $\mathrm{B}$, indicated that reducing protein supply by $20 \%$ impaired growth and protein deposition for fishes of this size. For all diets containing coffee pulp, all indices for growth, gain and food utilisation were worst than those obtain with both control diets. So strong depletion of results was not associated only to a bad utilisation of protein or energy supplying by coffee pulp but indicated also an interaction of coffee pulp content with others components of the diets. Among coffee pulp, silage process seemed to decrease parts of the anti nutritional effect observed with fresh coffee pulp. Silage slightly improved protein and fat deposition and/or utilisation. For each coffee pulp, fresh or ensiled, an excess of energy supply by addition of corn starch allowed a small amelioration in protein and energy utilisation. This suggested that negative impact of coffee pulp on growth and feed utilisation acted both on protein and energy utilisation, as part of decline in protein utilisation might be recovered improving the non-protein energy allowance. Moreover, digestibility of organic matter was improved with ensiled coffee pulp compared fresh one when excess of starch content were added to the diet, but not crude protein digestibility. If for fresh coffee pulp both protein and organic matter digestibility were distorted, silage process seemed to allow partial recovery of negative interaction between coffee pulp and digestibility of non-protein organic matter coming from others feedstuffs. From these results, coffee pulp, fresh or ensiled, could not be considered as valuable feedstuff for Nile tilapia. To this respect our data were in agreement with reports given on common carp, Cyprinus carpio, or catfish, Clarias mossambicus (Christensen, 1981) but not with those on Clarias isheriensis or an other tilapia species, Oreochromis aureus (Bayne et al., 1976; Fagbenro and Arowosoge, 1991). This difference could be related to the fact 
that previous studies were performed in fertilized pond in which contribution of natural food might not be excluded. Small amount of coffee pulp treated with $\mathrm{NaOH}$ were added to the diet of $O$. aureus grown in aquaria with limited effect on growth and protein deposition (Ulloa Rojas and van Weerd, 1997). In this experiment, protein from coffee pulp represented nearly $3 \%$ of total crude protein allowance and $4 \%$ of gross energy allowance. Comparative data obtained with only $97 \%$ of total crude protein allowance without coffee pulp are necessary to check if results differ in the same range when coffee pulp is present or absent. Among causes likely to impair overall growth and food utilisation performance with coffee pulp, anti nutrient factors as tannins and polyphenols are susceptible. Tannins are reported to damage protein digestibility as well as assimilation either through interaction of tannin with dietary protein or through inhibition of digestive proteases (Bravo, 1998; Reed, 1995). In vitro studies of tannins extract from coffee pulp indicated highest binding capacity when polyphenols to protein ratio was equal to $1: 2$ (Velez et al., 1985). Tannins contents of coffee pulp are reported to be around 2 to $4 \%$ of dry matter (Ramirez Martinez, 1999). This might be sufficient to interact with protein of coffee pulp and should be not enough to complex those from other ingredients, considering the previous described 1:2 optimum polyphenol/protein ratio. Significant inhibition of trypsin from intestinal lumen and dipeptidase for intestinal mucosa have been observed on broiler cockerel with a tannin incorporation level of $13.5 \mathrm{~g} \mathrm{~kg}^{-1}$ food dry matter (Ahmed et al., 1991). Considering tannin level given for coffee pulp, amount of coffee pulp used in our experiment could be sufficient to induce such inhibition. Moreover, inhibition of amylase and lipase by tannin were also described (Longstaff and Mc Nab, 1991; Quesada et al., 1996; Tamir and Alumot, 1969). This could also explain the observed poor utilisation of feed as a whole. Even if results obtained with both kind of coffee pulp were not good, a significant improvement was observed using ensiled coffee pulp rather than fresh one. Such improvement was not sufficient to retain ensiled coffee pulp as suitable feedstuff for fish feed, but it indicated that during the silage process some modifications happen which could act to reduce adverse nutritional impact of coffee pulp. Slight change in tannin content was reported during the silage process (Perraud-Gaime Personnal communication). However, tannin and overall polyphenol content determinations are highly dependent of the nature of polyphenols present (Reed, 1995) and should be interpreted with special care. Therefore, even if the observed modifications in the tannin content during silage process were not important, quality modification of this content might be sufficient to significantly improve nutrient utilisation of the feed and explain difference of organic matter digestibility between the two coffee pulps. Development of specific HPLC analysis should allow better characterization of tannins in fresh and ensiled coffee pulp. Depleted effect due to caffeine content should not be considered, as this component was not significantly modified during silage.

\section{CONCLUSION}

Growth was highly depleted by inclusion of fresh or ensiled coffee pulp in the diet. Coffee pulp sharply impaired dietary protein and energy utilisation of all food ingredients. Fresh or ensiled coffee pulp should not be considered as suitable feedstuffs for Nile tilapia. Adverse effects of coffee pulp inclusion were probably due to their tannin content that interacted with dietary protein and/or digestive enzyme. Silage process significantly improved growth and feed utilisation comparing results obtained with fresh coffee pulp. More works are required on what happens during this process to identify which factors are involved, e.g. modification in tannin composition. This will help for further identification of process allowing valorisation of coffee pulp as feedstuff for fish.

\section{RESUMO}

Polpa de café ensilada foi utilizada na dieta calórica-protéica de Tilápia do Nilo na razão de $3.2 \mathrm{~g} \pm 0,2$ durante um período de 28 dias. As dietas calórico-protéica foram formuladas com base na ingestão diária permitida. Uma dieta $\mathrm{A}$ controle (100\% de proteína e $100 \%$ da energia) que corresponde a g $\mathrm{PC} / \mathrm{kg} / \mathrm{dia}$ e $750 \mathrm{Kj} / \mathrm{Kg} / \mathrm{dia}$, 
uma dieta B baixa em proteína ( $80 \%$ de proteína e $100 \%$ da energia), duas dietas C e E $(100 \%$ de proteína e $100 \%$ da energia) onde $20 \%$ da proteína foi suplementada com polpa de café e duas dietas $\mathrm{D}$ e F com a mesma concentração de polpa de café é prejudicial a dieta de crescimento. O processo de ensilagem melhorou sua utilização como alimento em comparação com a polpa de café fresca. Os resultados demonstraram que a polpa fresca ou ensilada não é para ser usada como alimentação de Tilápia do Nilo. Entretanto, uma melhor conhecimento do processo de ensilagem da polpa de café pode ser uma via importante para aumentar o valor nutritivo da polpa de café.

\section{ACKNOWLEDGEMENT}

This work is a part of the BIOPULCA project with the support of European Union (EU PROJECT INCO DC: $\mathrm{N}^{\circ}$ IC18*CT970185). We would like thank to Dr G. Saucedo-Castañeda, Dr M. Labat and Jean-Philippe Carralot for their help and/or technical assistance and to Frédéric Clota and Martial Derivaz (CIRAD-GAMET) for the production of juvenile tilapia.

\section{REFERENCES}

Abate, A. and Pfeffer, E. (1986), Changes in nutrient intake and performance by goats fed coffee pulpbased diets followed by a commercial concentrate. Anim. Sci. Technol., 14, 1-10.

Ahmed, A. E.; Smithard, R. and Ellis, M. (1991), Activities of enzymes of the pancreas, and the lumen and mucosa of the small intestine in growing broiler cockerels fed on tannIn: containing diets. Br. J. Nutr., 65, 189-197.

Aregheore, E. M. (1998), A review of implications of antiquality and toxic components in unconventional feedstuffs advocated for use in intensive animal production in Nigeria. Veterinary and Human Toxicology, 40, 35-39.

Bautista, E. O.; Useche, M.; Pérez, P. F. M. and Linares, F. (1999), Utilización de la pulpa de café ensilada y deshidratada en la alimentación de cachaway (Colossoma x Piaractus). In: Ramirez Martinez, J. R. (ed.). Pulpa de café ensilada. Producción, caracterización y utilización en alimentación animal. Universidad Nacional Experimental del Táchira (UNET), San Cristóbal, Estado Táchira, Venezuela. pp. 109-135.
Bayne, D. R.; Dunseth, D. and Ramiros, C. G. (1976), Supplemental feeds containing coffee pulp for rearing Tilapia in Central America. Aquaculture, 7, 133-146.

Bravo, L. (1998), Polyphenols: chemistry, dietary sources, metabolism, and nutritional significance. Nutr. Rev., 56, 317-33.

Cabezas, M. T.; Murillo, B.; Jarquin, R.; Gonzalez, J. M.; Estrada, E. and Bressani, R. (1974), Coffee pulp and husks. 6. Adaptation by cattle to coffee pulp. Turrialba, 24, 160-167.

Cho, C. Y.; Cowey, C. B. and Watanabe, T. (1985), Finfish Nutrition in Asia. IDRC, Ottawa, Ontario.

Christensen, M. S. (1981), Preliminary tests on the suitability of coffee pulp in the diets of common carp (Cyprinus carpio L.) and catfish (Clarias mossambicus Peters). Aquaculture, 25, 235-242.

Donkoh, A.; Atuahene, C. C.; Kese, A. G. and Mensah Asante, B. (1988), The nutritional value of dried coffee pulp (DCP) in broiler chickens' diets. Anim. Sci. Technol., 22, 139-146.

Fagbenro, O. A. and Arowosoge, I. A. (1991), Growth response and nutrient digestibility by Clarias isheriensis (Sydenham, 1980) fed varying levels of dietary coffee pulp as replacement for maize in lowcost diets. Bioresource Technology, 37, 253-258.

Gomez-Brenes, R.; Bendana, G.; Gonzalez, J. M.; Jarquin, R.; Braham, J. E. and Bressani, R. (1988), Effects of the treatment of coffee pulp, fresh or ensilaged, with calcium hydroxide, on its nutritive value. Arch. Latinoam. Nutr., 38, 173-87.

Gomez-Brenes, R. A.; Bendana, G.; Gonzalez, J. M.; Braham, J. E. and Bressani, R. (1985), Relationship between the included levels of coffee pulp and the protein content in rations for monogastric animals. Arch. Latinoam. Nutr., 35, 422-37.

Hart, F. L. and Fisher, H. J. (1971), Modern food analysis. Springer-Verlag, New York, USA .

Kaushik, S. J., Doudet, T., Médale, F., Aguirre, P. and Blanc, D. (1995), Protein and energy needs for maintenance and growth of Nile tilapia (Oreochromis niloticus). J. Appl. Ichthyol., 11, 290-296.

Longstaff, M. A. and Mc Nab, J. M. (1991), The effect of concentration of tannIn: rich bean hulls (Vicia faba L.) on activities of lipase (EC 3.1.1.3) and alphaamylase (EC 3.2.1.1) in digesta and pancreas and on the digestion of lipid and starch by young chicks. $\mathrm{Br}$. J. Nutr., 66, 139-147.

N. R. C. (1993), Nutrients requirements of fish. New York, USA : National Academy Press.

Okai, D. B. and Dabo, P. (1991), Further studies on the effects of diets containing dried coffee pulp: growth performance, blood and carcass characteristics of pigs. Beitr. Trop. Landwirtsch. Veterinarmed., 29, 235-241.

Pandey, A.; Soccol, C. R.; Nigam, P.; Brand, D.; Mohan, R. and Roussos, S. (2000), Biotechnological potential of coffee pulp and coffee husk for bioprocesses. Biochemical Engineering Journal, 6, 153-162. 
Perraud-Gaime, I.; Saucedo-Castańeda, G.; Augur, C. and Roussos, S. (2000), Adding value to coffee solid by-products through biotechnology. In: Sera, T.; Soccol, C. R.; Pandey, A. and S. Roussos (ed.). Coffee biotechnology and quality. Kluwer Academic Publ., Dordrecht, NL. pp. 437-446.

Quesada, C.; Bartolome, B.; Nieto, O.; Gomez Cordoves, C.; Hernandez, T. and Estrella, I. (1996), Phenolic inhibitors of alpha-amylase and trypsin enzymes by extracts from pears, lentils, and cocoa. J. Food Protect., 59, 185-192.

Ramirez Martinez, J. R. (1999), Pulpa de café ensilada. Producción, caracterización y utilización en alimentación animal. Universidad Nacional Experimental del Táchira (UNET), San Cristóbal, Estado Táchira, Venezuela .

Reed, J. D. (1995), Nutritional toxicology of tannins and related polyphenols in forage legumes. J. Anim. Sci., 73, 1516-1528.

Roussos, S.; Augur, C.; Perraud-Gaime, I.; Pyle, D. L.; Saucedo-Castańeda, G.; Soccol, C. R.; Pandey, A.; Ferrao, I. and Raimbault, M. (2000), Development of bioprocesses for the conservation, detoxification and value-addition of coffee pulp and coffee husk. In: Sera, T.; Soccol, C. R.; Pandey, A. and S. Roussos (ed.). Coffee biotechnology and quality. Kluwer Academic Publ., Dordrecht, NL. pp. 377-392.

SAS Institute Inc. (1989), SAS/STAT ${ }^{\circledR}$ User's Guide, Version 6. Sas Institute Inc., Cary, NC, USA .

Suzuki, E. Y. and Early, R. J. (1991), Analysis of chromic oxide in small samples of feeds and feces using chlorine bleach. Canadian Journal of Animal Sciences, 71, 931-934.
Tamir, M. and Alumot, E. ( 1969), Inhibition of digestive enzymes by condensed tannins from green and ripe carobs. J. Sci. Food Agric., 20, 199-202.

Ulloa Rojas, J. B. and van Weerd, H. (1997), The growth and feed utilization of Orechromis aureus fingerlings fed diets with various coffee pulp levels. Paper presented at Tilapia aquaculture. Proceedings of the fourth International Symposium on Tilapia in Aquaculture, Orlando, Florida, USA.

Velez, R. A. J.; Garcia, A. L. A. and Rozo, M. P. (1985), Interaction in vitro between polyphenols of coffee pulp and various proteins. Arch. Latinoam. Nutr., 35, 297-305.
Received: October 24, 2001; Revised: June 27, 2002; Accepted: December 20, 2002. 